\title{
Creating love for reading via inclusion of African talking drums in school library media centre activities
}

\author{
Dr. Fadekemi Oyewusi \\ Acting Director, \\ Centre for Educational Media Resource Studies, \\ University of Ibadan \\ Nigeria \\ fdkwusi@yahoo.com
}

\begin{abstract}
The African drum is an important instrument of communication in traditional African societies which serves as the voice of the whole community and it communicates desired information. Children that do not come to the school library media center can be attracted through the inclusion of African drums in her activities. This paper discusses ways through which children could be attracted to the school library media centers for her readership campaign programs through the use of the African talking drums. African drums can be used through role plays, songs, dances and dramas of literature such that children would get interested in reading accessible books in their library. The paper talks about who plays the drum and the indigenous African stories that include the use of drums as a medium of communicating story themes. The paper also highlights some activities carried out by a school library media center in Nigeria (with graphic details) on how some of these drums were utilized. Pictorial examples and presentation of the African drums would be presented during discussions. The African Drum should be seen as a significant technique that could be used in attracting children back to read in the school library media center.
\end{abstract}

Keywords: Talking drums, School library, Africa, Reading, Inclusion

\section{Background to the study}

Children in developing countries like mine do rarely make use of the school library. This is due to several reasons associated with cost of keeping the school libraries up to date with new books and adequate space to store them. This has made the libraries unattractive and inconvenient for children to work individually and in small groups. Even in developed countries with libraries with high windows, nice carpet, adequate lightening, and baskets full of great books, children still have their personal reservation as regards the use of such library. Libraries in the developed countries are better equipped than libraries in developing countries. However, most parents in developed countries read aloud to their children when they are young, which is a strategy for imbibing reading culture. Even when kids can read books themselves, these parents continue to read to them. Some parents worry that their kids are not reading enough books while others worry that the books their kids are not reading enough. This is not the case in developing countries! This brings the teaser question, 
"why would children not go to the library in their numbers where the books and resources are available and accessible?" What can be done to get children interested in reading for pleasure and in visiting the library without forcing them (despite the friendly or unfriendly nature of some school libraries as the case may be). Then I thought of music! Introducing the use of African Drums into school library activities is a wonderful way to get children into the library to read. What about the noise in a library setting? The library is expected to be a serene environment. However, a children/school library can be allowed to include fun activities like music and drumming once in a while or during special activities. Drumming activities would attract children who might not otherwise come to the library because such programs would attract large numbers of children to the library, especially during the library hour, reading seminars or summer period when reading often decline.

According to Celano and Neuman (2001), libraries for children and young adults have had several tasks to perform

- to provide services, materials, and opportunities for those who need them to develop literacy skills;

- to become part of the educational system;

- to extend traditional library functions (support and resources) to patrons with developing literacy skills;

- to try nontraditional ways of serving newly literate populations;

- to interpret resources;

- to be proactive in education, dissemination of information, and promotion of resource use; and

- to collaborate with other agencies in literacy programming.

From the perspective of the promotion of library use, drumming could be introduced as a game activity for children and young adults. At every activity organized by my school library (which is part of the Centre for Educational Media Resource Studies, a research center in at the University of Ibadan, Nigeria), we allow the use of African drums to accompany activities such as reading of poems from books, drama, dances, clapping to rhythm of drums during reading campaign seminars, story hour periods, and other school library activities. We notice much excitement in the children when they participate in these library activities.

\section{Introduction}

The possibility of introducing other cultural resources into school library activities was underscored when Boustead (2015) he observed that the library is no longer simply "a quiet place" to access "physical content". According to him, "it is instead a place, physical and virtual, to learn how to connect and use resources of all types from physical books to apps to experts in a local, regional, or national community. It is a kitchen for 'mixing resources' in order to empower teens to build skills, develop understanding, create and share, and overcome adversity".

This could be done when drumming is transformed into a game activity in the school library. Drumming is not an experience that only music therapists can use. Many library professionals with a little bit of training can use drum and percussion experiences to help children in cognition and literacy. Gaming is gradually growing as a new media alongside books, music, and films as a way of both recreation and education. It is necessary to bring this into library activities in order to invite more children into the school library. Some 
children/teens do not visit the library because the environment is not inviting and interesting. The school library should offer its community a place for meetings with divers activities throughout the year. It is necessary for the school library to give children opportunities to read as much as they can and to make a lasting change in their community. School libraries should no longer be considered a quiet and boring area. The key to successful school libraries is to balance study and reading with fun activities that stimulates children and inspire them to explore further. Most school libraries around the world are not inviting and stimulating enough. Most of the books that fill the shelves are very old and outdated due to budget cut, dwindling finances, expensive library resources etc. Thus, when it comes to encouraging children into the school library, a little incentive is required. This can be done by thinking up creative ideas for activities that can draw children into the library.

Drums are also excellent tools for to promoting learning in a fun-filled way in the library. This is because drumming helps to exercise the mind, an excellent way to encourage more boys into the library. Fun exercises help to limber up the brain and improve learning. The school library is one of the most important buildings in a child's life, where a child may learn to love books and reading; it might also be where he/she develop problems of reading and spelling skills (Lopez, n.d.). By incorporating fun library activities into the school's library, we can increase children's chances of associating reading and books with fun. By introducing drumming activities into the school library activities, an environment where children want to come and read would be created. Does your library orientation plan feel a bit stale? Have you been doing the same lesson for the last few years (or more)? Do you feel bored just thinking about your regular library programs? Libraries and librarians can reap positive gains by proactively, creatively, and affordably integrating drumming activities into the services and programs already offered at the school library.

School libraries can strife to meet the needs of the school community in which it resides through the introduction of African Drums into her activities. African drums are part of most occasions in Africa, from wedding to funeral to religious functions. Every African drum is different from the other and no two drum sound similar. Each has its own significance in the lives of the African people. Most of these drums have been in vogue for hundreds or thousands of years. For example, the talking drums of the Yoruba people of the SouthWestern of Nigeria are like many other types of drums found in other parts of the world in that they are melody producing/enhancing musical instruments accompanying song and dance performances. They are made of hollow round frame with tightly fixed plastic or skin membrane on the surface(s) which are beaten with the hand(s), stick(s) or other materials. However, the Yoruba talking drums of the South West people of Nigeria are unlike the many other types of drums found in other parts of the world in that they are not just melody producing/enhancing musical instruments; they are used also for communication purposes. Traditional communication is a vital human activity which touches every sphere of life for meaningful development and peaceful co-existence in African society. This is basically because they can be used to disseminate vital messages and to respond to disseminated information (Oluga and Babalola, 2012). It involves the acts of transmitting messages to channels which link people to their languages and symbolic codes through which information are impacted and shared from one person to another (Agbenu, 2007). Festivals are integral parts of life in the rural African communities. During such festivals, drums, drama and roleplay are used not only as a means of entertainment but also as a means of imparting socially accepted norms and values. Drums can be used during poetry performances, oral narratives, 
stories, songs, role-play, incantations, drama, body movement-dances, games and expressive play activities.

\section{Understanding the African Talking Drum}

The talking drum is an African Hourglass drum whose pitch can be regulated to mimic the tone and prosody of human speech. The talking drum is closely tied to the Yoruba language in Nigeria. Yoruba is a tonal language, which means that different pitches of a sound have different meanings. One of the unique features of the Talking Drum instrument is its ability to closely intimate the rhythms and intonations of the spoken language.

The Talking Drum occupies an important position in traditional African society. It is the most useful method of traditional communication which helps in information dissemination in traditional African society.

Traditionally, the talking drum is used for:

- Ceremonial song- sung at marriage, house warming, naming, anniversaries, chieftaincy installation, etc.

- Praise song- sung when a task is accomplished, or after victory in a war.

- Burial/mourning song- for example when evil befalls, a catastrophe happen, during financial loss, disaster, epidemics, etc.

- Traditional religious song- for festivals, masquerade, planting, harvest

- Festivals,

- The Talking Drum warns and limits the Obas (Kings) from wrong doings and makes them conscious of their deeds. (Ebeze, 2002).

Some of the talking drums among West African ethnic groups:

- Tama (Wolof of Senegal)

- Gan gan, Bata, Dun Dun (Yoruba of Nigeria and eastern Benin)

- Dondo (Akan of central Ghana and Cote d'Ivoire)

- Lunna (Dagomba of northern Ghana; Mossi of Burkina Faso)

- Kalangu (Hausa of northern Nigeria, Niger, northern Ghana, Benin and Cameroon)

- Doodo (Songhai and Zarma of Mali, Burkina Faso, and Niger) (Wikipedia, 2014). There are different types of African drums that could be adopted into the school library setting. However, in this paper, attention will be focused on two talking drums from the Yoruba of South Western Nigeria: Bata drums and Gangan (the hourglass talking drum)

- Bata Drums: This is a famous African drums used by the Yoruba people of Nigeria. The bata drums essentially are made up of a combination of three or five drums, all of different sizes. These can be played either with a stick or with one's hand. The two ends of the drums are not of the same size with one end having a large head and the other end having a smaller head with the neck tapering down. . Though the bata drums are African in origin they were introduced to the Cuban people by the African slaves who brought these drums to Cuba as part of their religious practices.

- Talking Drums: The most interesting and famous variety of drums are the talking drums of Africa. Any drum whose pitch can be modulated to sound like words in the local language can be termed as a talking drum. While the bata is also called a talking drum, this term can be applied to any of the African drums. Talking drums come in different shapes, with only the hour glass shape and two leather-covered heads being common to all of them. The pitch of the drums is adjusted through the strings. They are usually played with a stick. A type of the talking drum is the Dundun ensemble. This is the hour glass drum commonly referred to as the talking drum. Most Yoruba 
drums mimic speech (talk). It leads the talk, dictates the pace, determines the song etc.

The pitch of the drum is varied to mimic the tone patterns of speech. The waist of the drum is held between the player's arm and ribs, so that when squeezed the drumhead is tightened, producing a higher note than when it's in its relaxed state; the pitch can be changed during a single beat, producing a warbling note. The drum can thus capture the pitch, volume, and rhythm of human speech, though not the qualities of vowels or consonants (GertjegerdesMyricks, 2002).

\section{The use of talking drum in readership campaigns for children}

The school library is central to learning and plays a key role as a place for encouraging innovation, curiosity, and problem solving. To get the interest of children back to reading the talking drums could be used in the school library during book talks, story-telling, summer reading camps and communication to children. Before the advent of the current form of Information and Communication Technology (ICT), the Yoruba had been involved in several ways of communication (without vocal expression).

The school librarian can promotes reading and literacy with African drums in the following ways

1. Before the start of each special program to be hosted by the library, the drums would be beaten to attract children to the library activity. Sometimes during break time and lunchtime the school library can become a site of drumming activities.

2. Talking drums performance can include an interpreter among the children which may be of comic effect.

3. The drummer (in case of a public library) takes the drum around the immediate environment and tells children to come to the library for more. This would attract them into to the library.

4. Literature is the ideal vehicle for helping children to see the importance of numbers in their daily lives. Drumming activities in libraries involving counting could help out.

5. Theme Activities: Since librarians are in charge of all the books in the library, they can choose themes and have weekly activities around that theme with drumming to accompany. For example, a librarian can collect all the art books and have the children create drumming activity based on what they see/read in the books.

6. Children could be allowed to beat the drum for five minute before they start reading the library books during a drum break. Children would want to come back, especially if it is their turn in a particular week. This encourages audience participation.

7. During special programs organized by the library, school(s) could use drums only or with songs and dance to disseminate information about the importance of reading and the library to participating children. Drumming activities and games can presents dozens of book-themed activities, lessons, and projects.

8. Parents can be involved in drumming games/activities with their children in the library.

9. Pictures of the children could be taken with the library drum/ drummer and presented to them during their birthday or posted on the library board or website as an award for the consistent library user of the month.

10. The library is a place where curiosity and creativity are encouraged 


\section{Drumming as a form of activity game}

In a world of apps, online games, connected mobile devices, and game consoles have made the physicality and social aspect of gaming to dwindle. This is because players become more detached and do not have contact with other people. The school library is positioned to foster innovation, inquiry and curiosity through these activities. When children drum together in the library setting, it allows them to connect and build social relationships with other students. Children who typically would sit alone on the playground can find a connection with others through a gaming program. According to Nicholson (2008), libraries have been using games as part of their services for decades. In fact, researches have traced gaming in libraries back to 1855 at the Mechanic's Institute Library in San Francisco, which had a chess room. In addition, librarians have no problem with a quiet game and many libraries make these and similar games available. However, there are more and more evidence that games in general assist children to develop a wide range of useful skills. Drumming as a game event is not as well known or appreciated by the library world. However, drumming events in libraries as a game can generate great publicity and create a strong, lasting connection between children/teens and the library as an institution that supports and encourages the activity that they love so much. The idea of electronic game events in the library has become popular to the point of being innocuous and intergenerational especially with the advent of the Wi-Fi and mobile gaming.

Drumming activities like other games when introduced in the library as certain benefits as shown by Techsoup for library publication (n.d):

- Draw teens and their parents to the library. Librarians need not worry that they are losing their user because teens now visit the library less often and check out fewer books because their entertainment options have now increased. Drumming events in the library will increase circulation and reading among young adults.

- Create a connection between young adults and library staff. Teens are more likely to ask for help from someone they know.

- Help teens develop teamwork and organizational skills. A lot of libraries involve teens in planning and monitoring their game nights. Teens help select the games, market the events, set up equipment, enforce time limits and so on. Furthermore, the drumming event will often require teamwork and cooperative problem solving.

Drumming as a game activities have the following advantages

1. Drumming can help students grow academically; it can improve students' ability to concentrate and compliment their studies in most subjects.

2. Player interaction helps foster unity with fellow group members all playing together. Drumming will help children relax from studying and develop connections with each other.

3. Physical strength gained by aerobic exercise. This helps increased heart rate which aids blood flow and body metabolism. It also builds valuable skills for processing and communicating information, and containing or channeling intense emotions and impulses.

4. Ease of public-speaking and social situations. Someone among them may need to introduce or interpret what the drumming is talking about. In general, the increasing of rhythmic skills and the learning of any musical instrument increases students' confidence.

5. Higher self-esteem: Drumming is an excellent way for children to learn selfawareness, listening skills, coordination of breath and movement, cooperation and 
patience. For example, if children have low self-esteem, depression, anxiety, defiant behavior, learning disabilities, attention deficit disorder or simply an abundance of energy, drumming can be a valuable aid to learning and growth. Intelligence and rhythmic accuracy go hand in hand.

6. According to scientific research, playing music, and hence drumming and playing percussion, increases the development of various regions of the brain.

7. Playing drums and rhythms can be an optimal experience and encourages participants of all ages to achieve flow.

8. Playing rhythms improves listening skills and increases children and teens' ability to focus for extended periods of time.

\section{Conclusion}

School libraries will always exist as places for learners to find information, resources, services, and instruction. This is because formats, technologies, learning needs, schools and students themselves are evolving. The school library landscapes have shifted all around the world and will continue to shift. School libraries and school librarians with creative planning and little money can incorporate drumming activities into their library activities for a big return on investment. The activities planned by a library can allow the imaginations of the users run free, introduce them to new experiences and promote access to knowledge and enjoyment that will promote reading. It is important for these children/teens to become independent users of information. For this to occur, it is vital that they are given the skills to learn how to find this information, to select what is relevant, and how to use it in the best way for their own particular needs, and take responsibility for their own learning. Drumming activities would bring fun ideas into the normal library setting that are sure to get children across the grades excited about reading. For school libraries to meet the needs of her users today, drumming activities would allow young people participation which should be integrated throughout the school library program.

\section{References}

Oluga, Samson Olasunkanmi and Babalola, Halira Abeni Litini (2012). Drummunication: The Trado-Indigenous Art of Communicating with Talking Drums in Yorubaland. Gobal Journal of Human Social Science Arts and Humanities. Volume 12 Issue 11. Available at https://globaljournals.org/GJHSS Volume12/5-Drummunication-TheTrado-Indigenous.pdf

Gertjegerdes-Myricks, Petra (Jul 17, 2002). "African American History Village Receives New African Drums". Columbus Times. Retrieved 2 May 2013

Wikipedia (2014) Talking drum. Available at http://en.wikipedia.org/wiki/Talking drum

Ushe, Mike Ushe, (2014) The Talking Drum: An Inquiry into the Reach of a Traditional Mode of Communication. Journal of Culture, Society and Development. An Open Access International Journal Vol.12013

Cantwell, Alice M. 2001 A Five-Year Program Enhancement Plan For A Secondary School's Library and Information Program. Available at http://home.earthlink.net/ alcantwell/portfolio/HSLibFiveYearPlan.pdf 
Eve (n.d,) School Library Activities http://www.ehow.com/way 5262221 school-libraryactivities.html

Celano, D and Neuman, S. B. 2001. The Role of Public Libraries in Children's Literacy Development An Evaluation Report. http://www.ifpl.org/Junior/studies/Role\%20of\%20Libraries.pdf

TechSoup for Libraries (n.d) Gaming in Libraries http://techsoupforlibraries.org/cookbook3/innovation/gaming-in-libraries

Nicholson, S. (2008). Games in Libraries: Myths and Realities. NYLA Bulletin 56 (4), 3. Available at http://scottnicholson.com/pubs/fivemyths.pdf 